\title{
Examining the Career Paths of Athletic Administrators in NCAA-Member Institutions
}

\author{
Angela Lumpkin ${ }^{1, *}$, Rebecca M. Achen ${ }^{2}$, \& Sean Hyland ${ }^{2}$ \\ ${ }^{1}$ Department of Health, Exercise, and Sport Sciences, Texas Tech University, Lubbock, Texas, USA \\ ${ }^{2}$ Department of Health, Sport, and Exercise Sciences, University of Kansas, Lawrence, Kansas, USA \\ *Corresponding author: Department of Health, Exercise, and Sport Sciences, Texas Tech University, Lubbock, Texas, \\ USA. E-mail: angela.lumpkin@ttu.edu
}

Received: February 13, $2015 \quad$ Accepted: March 30, $2015 \quad$ Online Published: April 7, 2015

doi:10.5430/mos.v2n2p45 URL: http://dx.doi.org/10.5430/mos.v2n2p45

\begin{abstract}
Very little is known about the educational and experiential backgrounds of athletic administrators. The purpose of this study was to investigate these backgrounds in collegiate athletic departments. Results indicated significant differences across the three National Collegiate Athletic Association divisions and between males and females related to the educational and experiential backgrounds of athletic administrators, exclusive of athletic directors. Division I administrators were significantly more likely to have a doctorate, more years of experience working in intercollegiate athletics, and no coaching experience. Males were more likely to hold positions in facilities and media; females were more likely to work in academics and compliance. Overall, female administrators were significantly more likely than males to have a master's degree, prior experience working in intercollegiate athletics, and head coaching experience.
\end{abstract}

Keywords: intercollegiate athletics; athletic administrators; educational backgrounds; career paths

\section{Introduction}

Athletic directors, who are arguably the face of intercollegiate athletic programs, are studied much more than those who labor behind the scenes in athletic administrative positions (Hardin, Cooper, \& Huffman, 2013). In smaller institutions these administrators fulfill a plethora of responsibilities. However, at institutions with multimillion-dollar budgets, they work in highly specialized areas, such as facility and event management, with many employees reporting directly to them (Lumpkin, Dodd, \& McPherson, 2014). Although college sports have grown into business enterprises, little is known about the overall educational backgrounds and career paths of the athletic administrators, exclusive of athletic directors, operating these programs in institutions competing in the National Collegiate Athletic Association (NCAA).

College athletic departments join the NCAA in one of three competitive divisions that differ in revenues and expenses as well as philosophy. At the highest competitive level, there are extensive varsity sport opportunities and sponsorship of spectator-oriented, income-producing football and basketball teams competing against other Division I institutions (National Collegiate Athletic Association, 2014a). Division II emphasizes the experiences of student-athletes and their personal learning and development along with high-level athletic competition (National Collegiate Athletic Association, 2014b). Institutions belonging to Division III offer athletics as an integral part of students' educational experiences (National Collegiate Athletic Association, 2014c).

Given the philosophical differences across the divisions and mostly male control over intercollegiate athletics (Acosta \& Carpenter, 2012), it is important to examine who these athletic administrators are and whether their career backgrounds and experiences differ. The purpose of this descriptive study is to examine and explicate the characteristics of athletic administrators' career preparation and advancement among all member institutions of the NCAA. 


\section{Review of Literature}

Many researchers have explored the dominance of males as intercollegiate athletic administrators. For example, in 2012 there were no female administrators in $9.2 \%$ of athletic departments in NCAA-member institutions (Acosta \& Carpenter, 2012). They also reported these average numbers of female athletic administrators per institution: 1.78 in Division I, 1.24 in Division II, and 1.25 in Division III. Lumpkin et al. (2014) found significant differences between the number of males and females in athletic administration, with males holding most positions. In Division I, males served as $79.1 \%$ of deputy or executive athletic directors, $67.8 \%$ of senior associate athletic directors, $69.3 \%$ of associate athletic directors, and $70.5 \%$ of assistant athletic directors. Significant differences also were reported in Divisions II and III: $52.9 \%$ and $70.6 \%$ of senior associate athletic directors, $59.8 \%$ and $53.7 \%$ of associate athletic directors, and $61.1 \%$ and $62.9 \%$ of assistant athletic directors were males respectively. NCAA data for 2010-2011 revealed $66 \%$ of associate and assistant athletic directors were males (Wilson, 2012). Lapchick, Hoff, and Kaiser (2011) reported males held most associate and assistant athletic director positions in 2008-2009: 69\% in Division I, $58 \%$ in Division II, and 54\% in Division III. Clearly, NCAA institutions remain largely controlled by males who hold most athletic administrator positions at all competitive levels.

This control is exacerbated by the old boys' club, which allows males to control the most senior levels of management within intercollegiate athletics as they systematically minimize the intrusion of women into the inner circle (Whisenant, Pedersen, \& Obenour, 2002). Female athletic administrators (84\%) argue the old boys' club is a barrier to career advancement and agree the lack of an old girls' club contributes to the small number of female administrators in intercollegiate athletics (Young, 1990).

While a few researchers (e.g., Fitzgerald, Sagaria, \& Nelson, 1994; Hatfield, Wrenn, \& Bretting, 1987; Spenard, 2013; Wright, Eagleman, \& Pedersen, 2011) reported on the degrees and programs of study for athletic directors, studies seldom included information about other athletic administrators. In the only study found that examined educational backgrounds of other athletic administrators, Weaver and Chelladurai (2002) reported female associate athletic directors and assistant athletic directors in Divisions I and III had earned significantly higher percentages of master's degrees and doctorates than males serving in the same positions. Fuchs (2003) studied 65 female athletic directors, most with previous experience in athletic administration, and found $78.5 \%$ had earned a master's degree and $16.9 \%$ a doctorate while 3 held only bachelor's degrees. The most frequent programs of study for master's degrees, reported Fuchs (2003), were physical education (37.9\%) and sport management or athletic administration (34.5\%); for the doctorate, these programs of study were education (36.4\%), athletic administration (18.2\%), and organizational leadership (18.2\%). Recent research has not examined whether these degree patterns have changed, giving sport management faculty and students little understanding of what programs of study are valued in intercollegiate athletics.

Studies have examined the prior experience of athletic directors in the NCAA. Hatfield et al. (1987) reported that among athletic directors in 58 Division IA institutions with football programs, 29.3\% had served as associate athletic directors and $48.2 \%$ as assistant athletic directors. In studying Division III athletic directors who had worked at their current institutions zero to 29 years fulfilling a variety of administrative responsibilities, Pack (2002) found they had served in their roles for an average of less than 10 years. Fuchs (2003) studied the career paths of female directors of athletics and found $46.6 \%$ previously had served as associate athletic directors and $44.8 \%$ as assistant athletic directors; and they had worked in athletic administration for a mean of 14.7 years.

Also, work experience of female athletic administrators has been examined. In their study of 380 senior woman administrators (SWA), Lough and Grappendorf (2007) argued career advancement was based on years of experience, number of positions held, and areas of responsibility. Coaching, according to SWA respondents, was the most important career entry point. Most females (88\%) working in athletic administration previously coached at the collegiate level, reported Fuchs (2003), as did almost all of the 19 Division I female athletic directors studied by Grappendorf, Lough, and Griffin (2004). Fitzgerald et al. (1994) added,

...coaching positions continue to be the power positions with line responsibilities and, in some sports, with considerable visibility. Thus coaching roles and responsibilities may better prepare an individual for the AD position than does serving as an assistant or associate director. (p. 23)

While research has examined experience and career entry points for athletic directors, females, and Division III administrators, comprehensive information on the prior experience of athletic administrators was not found.

Additionally, research into the positions held by male and female athletic administrators is scant. Lumpkin et al. (2014) studied the sex of athletic administrators responsible for academics, finance, compliance, facility and event 
management, fund raising, licensing, marketing, media relations, and ticket operations. Significantly more males were responsible for facility and event management, media relations, and marketing in the three NCAA divisions. Females were disproportionately found in academics (significant differences for Divisions I and II) and compliance (a significant difference for Division I). These authors concluded a glass ceiling persisted in intercollegiate athletics to the detriment of opportunities for females.

SWAs stated females were much more likely to be hired into academic services and compliance, rather than external roles such as oversight of sport teams or fundraising (Lough \& Grappendorf, 2007). SWAs urged females not to work in academic services and compliance because these were not highly visible or powerful positions. They added that holding the SWA title often was career-limiting. Hoffman (2011) argued that when females were hired in academic services or compliance, even with titles of assistant or associate athletic director, they were unlikely to develop fundraising and administrative skills often required for career advancement.

Whenever males reinforced a glass ceiling and protected their financial power base, females in Division I institutions were significantly more likely to be hired as assistant or associate athletic directors within the areas of academic advising, compliance, marketing, life skills, and sports information (Whisenant et al., 2002). Hardin et al. (2013) reported athletic directors, who statistically were mostly males, had previous employment in development and marketing. Burton, Grappendorf, and Henderson (2011) suggested females often were placed in jobs at the bottom of the organizational hierarchy, while males were hired into positions with greater power and decision-making opportunities. The lack of females in powerful positions that included decision-making opportunities perpetuated the male dominance in intercollege athletic administration.

The literature about educational and experiential characteristics of athletic administrators is quite limited. This review highlights that the limited research available focuses on explicating differences by sex about athletic administrators, with little describing differences across divisions. Based on this review of literature, which shows an overall lack of information about the educational and experiential characteristics of athletic administrators exclusive of athletic directors, this study seeks to answer the following research questions.

1. What are the educational backgrounds of athletic administrators? Do these differ across divisions or between sexes?

2. What are the experiential backgrounds of athletic administrators? Do these differ across divisions or between sexes?

3. Are males still more likely to be athletic administrators across all divisions?

4. What are the responsibilities of athletic administrators? Do these differ by across divisions and between sexes?

\section{Method}

This cross-sectional study design included a comprehensive review of all (a unique feature of this study) NCAA-member institutions to describe the academic preparedness and coaching and administrative experience of top athletic administrators. After we split the divisions, our team discussed what information from athletic administrator biographies needed to be collected to answer the research questions. We determined sex, highest level of education, educational institution for both bachelor's and master's degrees, prior athletic experience, prior coaching experience, tenure in current position, and position title should be collected. Next, we collectively reviewed multiple websites across the three divisions to determine availability of information and how to code information to create a codebook to facilitate consistent and reliable data collection. We met again to make changes to how data were collected based on issues identified through this initial process and finalized coding procedures. Then, we began final data collection for every university across all three NCAA Divisions. Information was collected during the 2012-2013 academic year.

Top athletic administrators are operationally defined as the highest ranking administrator, exclusive of athletic directors, in each of the departments identified for this research. The departments included Academics, Compliance, Development, Facilities, Finance, Marketing, Media, and Sports Administration. Biographies were coded for the top administrators in each department. For example, if an athletic department listed multiple assistant or associate athletic directors in marketing, only the associate or senior associate biography was included in the sample. In Divisions II and III, the individual in charge of compliance may have the title Compliance Director, so we included that individual in the data collected. 
For each administrator, we reviewed the place of education and employment. All available data were collected by visiting all athletic department websites of NCAA-member institutions and reading staff directory biographical sketches. For internal consistency and content validity, we only collected data by reading these online biographies and unless explicitly stated in the biography of each athletic administrator, nothing was assumed or inferred. To handle missing data, we used pairwise deletion and included all cases that had data on the specific variables included in each analysis.

To make comparisons across division and by sex on the number of athletic administrators that hold an assistant or associate athletic director title, all individuals with either title were counted, regardless of their inclusion in the biographical data collection. For example, some universities had multiple assistant athletic directors in the marketing department. All of these individuals were included in the count of athletic administrators.

Once data were collected, we double-checked information and discussed additional questions or issues needing clarification before compilation of data from all three divisions into one dataset. The databases were uploaded into SPSS Statistics Version 20 for statistical analysis: a database of administrator counts by institution and a database of all other information was organized by job title for each institution.

SPSS was used to compute frequencies, descriptive statistics, and crosstabs of the athletic administrators. Chi-square tests and analyses of variance (ANOVA) were run to determine if differences found in the data were statistically significant after which we discussed which results were significant and meaningful for reporting. In all significance testing, $p=.05$ was used. The Bonferroni method controlled for Type I error in all pairwise comparisons.

The numbers of institutions during the 2012-2013 academic year were as follows: 344 in Division I, 298 in Division II, and 440 in Division III. Data were collected on 1,769 administrators in Division I, 973 Division II administrators, and 874 Division III administrators. In Division I, $71.1 \%$ of administrators were males as were $64.6 \%$ in Division II and $69.2 \%$ in Division III.

\section{Results}

The highest degrees obtained for athletic administrators across divisions and by sex are reported as percentages in Table 1. A chi-square test determined there were differences across divisions in the percentage of bachelor's degrees, master's degrees, and doctorates of athletic administrators, $\chi^{2}(4, n=2,329)=62.47, p<.001$, Cramér's $\mathrm{V}=.12$. Follow-up pairwise comparisons indicated Division I administrators were more likely to have a doctorate and less likely to have only a bachelor's degree when compared with Division II, $\chi^{2}(2, n=1,810)=21.24, p<.001$, Cramér's $\mathrm{V}=.11$. In addition, Division I administrators were more likely to have a master's degree or doctorate but less likely to have just a bachelor's degree when compared with Division III, $\chi^{2}(2, n=1,695)=53.65, p<.001$, Cramér's V $=.18$. Division II administrators were more likely to have a doctorate and less likely to have just a bachelor's degree than Division III administrators, $\chi^{2}(2, n=1,153)=10.48, p=.005$, Cramér's V $=.10$.

Table 1. Highest Academic Degree

\begin{tabular}{lccc}
\hline & Bachelor's Degree & Master's Degree & Doctorate \\
\hline Division I & $33.7 \%$ & $57.3 \%$ & $9.0 \%$ \\
Division II & $42.3 \%$ & $53.3 \%$ & $4.4 \%$ \\
Division III & $48.4 \%$ & $50.1 \%$ & $1.5 \%$ \\
Division I Males & $37.8 \%$ & $53.7 \%$ & $8.5 \%$ \\
Division I Females & $24.3 \%$ & $65.5 \%$ & $10.2 \%$ \\
Division II Males & $46.9 \%$ & $50.2 \%$ & $1.9 \%$ \\
Division II Females & $33.6 \%$ & $59.1 \%$ & $7.3 \%$ \\
Division III Males & $52.9 \%$ & $45.7 \%$ & $1.4 \%$ \\
Division III Females & $38.4 \%$ & $59.7 \%$ & $1.9 \%$ \\
\hline
\end{tabular}

Separate chi-square tests were run between males and females in each division. In Division I, females were more likely to have a master's degree; males were more likely to have just a bachelor's degree, $\chi^{2}(2, n=1,176)=20.54, p$ $<.001$, Cramér's V $=.13$. Females in Division II were more likely to have a master's degree or doctorate, while males were more likely to have just a bachelor's degree, $\chi^{2}(2, n=634)=14.28, p=.001$, Cramér's $\mathrm{V}=.15$. In Division III, females were more likely to have a master's degree and males were more likely to have just a bachelor's degree, $\chi^{2}(2, n=518)=9.36, p=.009$, Cramér's $\mathrm{V}=.13$. The effect of the differences was greatest in Division II. 
Percentages were calculated for each academic major across division and by sex and are reported in Table 2. A chi-square test identified a difference in the frequency of different majors of the highest degree earned for each athletic administrator across divisions, $\chi^{2}(20, n=2,545)=233.12, p<.001$, Cramér's $\mathrm{V}=.21$. Follow-up pairwise comparisons were conducted to determine differences between the highest degrees held by administrators across divisions. In Division I, administrators were more likely to have a business degree or Juris Doctorate (J.D.) and less likely to have a journalism degree when compared with administrators in Division II, $\chi^{2}(10, n=1,469)=49.40, p$ $<.001$, Cramér's $\mathrm{V}=.18$. Division III administrators were more likely to have degrees in arts and sciences, communication, and physical education and less likely to have business, journalism, or J.D. degrees than Division I administrators, $\chi^{2}(10, n=1,360)=113.82, p<.001$, Cramér's $\mathrm{V}=.29$. Division II administrators were more likely to have a business degree, journalism degree, or J.D. and less likely to have arts and sciences, educational leadership, communication, or physical education degrees than Division III administrators $\chi^{2}(10, n=951)=81.04, \mathrm{p}<.001$, Cramér's V =.29.

Table 2. Major of Highest Degree

\begin{tabular}{lccccccccccc}
\hline & A\&S & Bus & Educ & Ed L & H Ed & Jour & Ph Ed & Sp Mg & Com & JD & Oth \\
\hline Division I & $9.1 \%$ & $22.6 \%$ & $7.1 \%$ & $2.3 \%$ & $1.9 \%$ & $3.5 \%$ & $6.2 \%$ & $31.2 \%$ & $5.4 \%$ & $6.7 \%$ & $3.9 \%$ \\
Division II & $10.9 \%$ & $17.2 \%$ & $7.5 \%$ & $0.9 \%$ & $1.1 \%$ & $6.0 \%$ & $8.3 \%$ & $28.7 \%$ & $7.5 \%$ & $7.5 \%$ & $2.5 \%$ \\
Division III & $16.4 \%$ & $12.4 \%$ & $7.1 \%$ & $2.6 \%$ & $1.4 \%$ & $1.4 \%$ & $12.6 \%$ & $30.6 \%$ & $14.5 \%$ & $0.7 \%$ & $0.2 \%$ \\
Division I Males & $7.6 \%$ & $23.8 \%$ & $6.1 \%$ & $2.7 \%$ & $1.9 \%$ & $4.6 \%$ & $4.6 \%$ & $32.4 \%$ & $6.5 \%$ & $6.6 \%$ & $3.3 \%$ \\
Division I Females & $12.2 \%$ & $20.1 \%$ & $9.2 \%$ & $1.6 \%$ & $2.0 \%$ & $1.3 \%$ & $9.5 \%$ & $28.6 \%$ & $3.3 \%$ & $6.9 \%$ & $5.3 \%$ \\
Division II Males & $10.5 \%$ & $15.4 \%$ & $5.8 \%$ & $0.9 \%$ & $1.2 \%$ & $8.7 \%$ & $7.3 \%$ & $31.7 \%$ & $8.7 \%$ & $1.5 \%$ & $8.4 \%$ \\
Division II Females & $11.8 \%$ & $20.4 \%$ & $10.8 \%$ & $1.1 \%$ & $1.1 \%$ & $1.1 \%$ & $10.2 \%$ & $23.1 \%$ & $5.4 \%$ & $4.3 \%$ & $10.8 \%$ \\
Division III Males & $13.0 \%$ & $13.3 \%$ & $8.1 \%$ & $2.8 \%$ & $1.4 \%$ & $1.8 \%$ & $8.4 \%$ & $31.9 \%$ & $18.6 \%$ & $0.4 \%$ & $0.4 \%$ \\
Division III Females & $23.7 \%$ & $9.6 \%$ & $5.2 \%$ & $2.2 \%$ & $1.5 \%$ & $0.7 \%$ & $21.5 \%$ & $28.1 \%$ & $5.9 \%$ & $1.5 \%$ & $0.0 \%$ \\
\hline
\end{tabular}

Note: $\mathrm{A} \& \mathrm{~S}=$ Arts and sciences, Bus $=$ Business, Educ $=$ Education, $\mathrm{Ed} \mathrm{L}=$ Educational leadership or educational administration, $\mathrm{H} \mathrm{Ed}=$ Higher education, Jour $=$ Journalism, $\mathrm{Ph}$ Ed $=$ Physical education (kinesiology, sport studies, sport psychology, exercise physiology), $\mathrm{Sp} \mathrm{Mg}=$ Sport management, $\mathrm{Com}=$ Communication, JD = Juris doctorate, Oth $=$ Other

Administrators were compared by sex separately in each division. In Division I, females were more likely to have degrees in arts and sciences or physical education, and males were more likely to hold journalism or communication degrees, $\chi^{2}(10, n=939)=30.94, p=.001$, Cramér's $\mathrm{V}=.18$. Females were more likely to hold education, business, or J.D. degrees and less likely to hold journalism or sport management degrees as compared to males in Division II, $\chi^{2}(10, n=530)=28.47, \mathrm{p}=.002$, Cramér's $\mathrm{V}=.23$. Finally, in Division III females were more likely to have degrees in arts and sciences or physical education and less likely than males to have a degree in communication, $\chi^{2}(10, n=420)=34.34, \mathrm{p}<.001$, Cramér's $\mathrm{V}=.29$.

The overall chi-square for whether administrators had intercollegiate athletic experience (determined by whether their biographies stated they worked in intercollegiate athletics at any point prior to their current position as an administrator) prior to being hired was significant, $\chi^{2}(1, n=2,337)=276.14, p<.001$, Cramér's $\mathrm{V}=.34$. Pairwise comparisons indicated Division I administrators (93\%) were more likely to have prior experience in intercollegiate athletics than Division II administrators $(63 \%), \chi^{2}(1, n=1,828)=250.66, p<.001$, Cramér's V $=.37$, and Division III administrators (88\%), $\chi^{2}(1, n=1,714)=8.39, p=.004$, Cramér's V $=.07$. At the Division II level, administrators were less likely to have intercollegiate athletic experience prior to their current jobs than administrators in Division III, $\chi^{2}(1, n=1,132)=94.51, p<.001$, Cramér's V $=.29$.

A significant chi-square indicated a difference by sex at the Division II level with females (53\%) less likely than males $(68 \%)$ to have experience in intercollegiate athletics prior to their first jobs in athletics, $\chi^{2}(1, n=623)=12.93$, $p<.001$, Cramér's $\mathrm{V}=.14$. The difference was significant at the Division III level, also females $(95 \%)$ were more likely to have prior experience as compared to males $(86 \%), \chi^{2}(1, n=509)=9.41, p=.002$, Cramér's V $=.14$. No significant differences in prior experience in athletics were found between Division I males $(93 \%)$ and females $(93 \%), \chi^{2}(1, n=1205)=.219, p=.64$.

Chi-square tests indicated there were no differences across divisions, $\chi^{2}(2, n=2,409)=4.97, p=.083$, or by sex in Division I, $\chi^{2}(1, \mathrm{n}=1,211)=.52, p=.47$, Division II, $\chi^{2}(1, n=644)=.02, p=.89$, or Division III, $\chi^{2}(1, n=554)=.03$, $p=.88$, on the rate of hiring individuals with an undergraduate degree from the current institution. A significant chi-square test indicated there were differences across divisions in athletic administrators having a graduate degree 
from their current institutions, $\chi^{2}(2, n=1,401)=24.05, p<.001$, Cramér's V=.13. Pairwise comparisons indicated Division III institutions were less likely to hire individuals with graduate degrees from that institution when compared with Division I, $\chi^{2}(1, n=1,552)=29.39, p<.001$, Cramér's $\mathrm{V}=.14$, and Division II, $\chi^{2}(1, n=1,082)$ $=23.75, p<.001$, Cramér's V $=.15$. Differences were not significant between Divisions I and II, $\chi^{2}(1, n=1,586)$ $=0.02, p=.89$. Differences between males and females were not significant for Division $\mathrm{I}, \chi^{2}(1, n=775)=.47, p$ $=.49$, Division II, $\chi^{2}(1, n=359)=1.86, p=.17$, or Division III, $\chi^{2}(1, n=266)=.06, p=.80$. Table 3 lists the percentages of athletic administrators who hold a bachelor's degree or master's degree from his or her current institution.

Table 3. Undergraduate and/or Graduate Degree from Current Institution

\begin{tabular}{lcc}
\hline & $\begin{array}{c}\text { Undergraduate } \\
\text { Degree from } \\
\text { Current Institution }\end{array}$ & $\begin{array}{c}\text { Highest Graduate } \\
\text { Degree from Current } \\
\text { Institution }\end{array}$ \\
\hline Division I & $25.8 \%$ & $22.6 \%$ \\
Division II & $29.2 \%$ & $24.2 \%$ \\
Division III & $23.6 \%$ & $9.7 \%$ \\
Division I Males & $26.4 \%$ & $21.8 \%$ \\
Division I Females & $24.4 \%$ & $24.0 \%$ \\
Division II Males & $29.0 \%$ & $26.7 \%$ \\
Division II Females & $29.5 \%$ & $20.4 \%$ \\
Division III Males & $23.8 \%$ & $10.1 \%$ \\
Division III Females & $23.2 \%$ & $9.2 \%$ \\
\hline
\end{tabular}

When examining whether or not athletic administrators had coaching experience, a chi-square test showed there were differences across divisions $\chi^{2}(6, n=2,468)=237.72, p<.001$, Cramér's $\mathrm{V}=.22$. Follow-up pairwise comparisons indicated Division I administrators were more likely to have no coaching experience and less likely to have high school or head coaching experience in college than Division II administrators, $\chi^{2}(3, n=1,883)=77.94, p$ $<.001$, Cramér's V $=.20$. Significantly more Division I administrators had no coaching experience, and fewer had head coaching experience in college than administrators in Division III, $\chi^{2}(3, n=1,797)=215.66, p<.001$, Cramér's $\mathrm{V}=.35$. Division II administrators also were more likely to have no coaching experience, more likely to have high school coaching experience, and less likely to have head coaching experience in college than Division III administrators, $\chi^{2}(3, n=1,256)=48.44, p<.001$, Cramér's $\mathrm{V}=.20$.

When looking at the differences in coaching experience by sex in each division, chi-square tests indicated Division I female athletic administrators were more likely than males to have head coaching experience in college, and males were more likely to have no coaching experience, $\chi^{2}(3, n=1,212)=25.78, p<.001$, Cramér's V $=.15$. In Division II, females were more likely to have head coaching experience in college than males, $\chi^{2}(3, n=671)=8.41, p=.04$, Cramér's $\mathrm{V}=.11$. Again, in Division III females were more likely to have head coaching experience in college, and males were more likely to have no coaching experience, $\chi^{2}(3, n=585)=15.72, p=.001$, Cramér's V $=.16$. Percentages across division and by sex within each division are listed in Table 4.

Table 4. Prior Coaching Experience

\begin{tabular}{lcccc}
\hline & None & $\begin{array}{c}\text { High School } \\
\text { Coach }\end{array}$ & $\begin{array}{c}\text { College } \\
\text { Assistant Coach }\end{array}$ & College Head Coach \\
\hline Division I & $81.0 \%$ & $1.5 \%$ & $8.1 \%$ & $9.4 \%$ \\
Division II & $63.8 \%$ & $4.0 \%$ & $10.7 \%$ & $21.5 \%$ \\
Division III & $53.0 \%$ & $1.0 \%$ & $8.0 \%$ & $37.9 \%$ \\
Division I Males & $83.2 \%$ & $1.9 \%$ & $8.2 \%$ & $6.7 \%$ \\
Division I Females & $76.0 \%$ & $0.5 \%$ & $7.9 \%$ & $15.5 \%$ \\
Division II Males & $66.2 \%$ & $4.5 \%$ & $11.0 \%$ & $18.2 \%$ \\
Division II Females & $59.0 \%$ & $3.1 \%$ & $10.1 \%$ & $27.8 \%$ \\
Division III Males & $57.2 \%$ & $1.2 \%$ & $8.8 \%$ & $32.8 \%$ \\
Division III Females & $43.2 \%$ & $0.6 \%$ & $6.2 \%$ & $50.0 \%$ \\
\hline
\end{tabular}

Is a line space needed here? 
A two-way ANOVA was run for years of experience in the current job across division and by sex for athletic administrators. The means, cell sizes, and standard deviations are reported in Table 5. The main effect of sex was significant, $F(1,2,088)=7.01, p=.008, \eta^{2}=.003$, as was the main effect of division, $F(2,2,088)=9.95, p<.001, \eta^{2}$ $=.009$, and the interaction effect, $F(2,2,088)=7.48, p=.001, \eta^{2}=.007$. The authors examined the main effects across division to address research questions using follow-up tests consisting of pairwise comparisons among the three divisions. The Tukey HSD procedure was used to control for Type I error and indicated Division I and Division II administrators had fewer years in their current jobs than Division III administrators. The difference between Division I and Division II administrators was not significant. Simple main effects for the interaction effect also were examined. The only significant difference between males and females was found in Division III where males had 2.25 more years of experience than females, $F(1,2,088)=17.69, p<.001, \eta^{2}=.008$.

Table 5. Total Number of Years of Experience in Current Position

\begin{tabular}{lccc}
\hline & Mean & $n$ & Standard Deviation \\
\hline Division I & 5.15 & 1,008 & 4.73 \\
Division II & 5.19 & 614 & 5.54 \\
Division III & 7.02 & 472 & 5.77 \\
Division I Males & 5.13 & 4.90 & 707 \\
Division I Females & 5.20 & 301 & 4.33 \\
Division II Males & 5.15 & 407 & 5.63 \\
Division II Females & 5.26 & 207 & 5.37 \\
Division III Males & 7.65 & 340 & 6.13 \\
Division III Females & 5.40 & 132 & 4.32 \\
\hline
\end{tabular}

A series of one sample t-tests revealed differences between the mean number of male $(\mathrm{M}=3.58)$ and female $(\mathrm{M}=$ 1.52) associate athletic directors across Division I, $t(686)=12.48, p<.001$. This difference also was significant for Division II male $(\mathrm{M}=.53)$ and female $(\mathrm{M}=.38)$ associate athletic directors, $t(604)=2.79, p=.005$. This difference also was significant for the number of male $(\mathrm{M}=2.66)$ and female $(\mathrm{M}=.99)$ assistant athletic directors in Division $\mathrm{I}$, $t(686)=12.59, p<.001$, male $(\mathrm{M}=.77)$ and female $(\mathrm{M}=.40)$ assistant athletic directors in Division II, $t(604)=5.79$, $p<.001$, and male $(\mathrm{M}=.48)$ and female $(\mathrm{M}=.32)$ assistant athletic directors in Division III, $t(878)=3.83, p<.001$.

Table 6. Top Five Job Responsibilities by Division and Sex

\begin{tabular}{ccccc}
\hline Rank & Male & \multicolumn{2}{c}{ Female } \\
\hline & & Division I & Academics & $23.2 \%$ \\
1 & Media & $18.8 \%$ & Compliance & $23.0 \%$ \\
2 & Facilities & $18.4 \%$ & Academics/Compliance & $10.4 \%$ \\
3 & Development & $15.0 \%$ & Marketing & $9.4 \%$ \\
4 & Marketing & $11.1 \%$ & Finance & $7.4 \%$ \\
5 & Compliance & $8.8 \%$ & & \\
& & Division II & Compliance & $37.5 \%$ \\
1 & Media & $34.8 \%$ & Business & $17.2 \%$ \\
2 & Facilities & $15.6 \%$ & Academics & $11.9 \%$ \\
3 & Compliance & $11.8 \%$ & Academics $/$ Compliance & $7.3 \%$ \\
4 & Development & $9.1 \%$ & Media & $7.0 \%$ \\
5 & Marketing & $7.0 \%$ & & \\
& & Division III & Compliance & $23.0 \%$ \\
1 & Media & $52.6 \%$ & Media & $19.3 \%$ \\
2 & Facilities & $20.7 \%$ & Business & $15.2 \%$ \\
3 & Compliance & $9.6 \%$ & Facilities & $14.1 \%$ \\
4 & Academics & $3.5 \%$ & Academics & $12.6 \%$ \\
5 & Business & $3.0 \%$ & &
\end{tabular}

To examine patterns and illustrate differences in job responsibilities across each division and by sex, percentages of individuals in each job responsibility were calculated. Table 6 lists the top five job titles held in each division 
separated by sex. In Division I, females were more likely to hold positions in academics, compliance, and sports administration, and males were more likely to hold positions in development, facilities, and media, $\chi^{2}(42, n=1769)$ $=403.42, p<.001$, Cramér's V $=.48$. Females in Division II were more likely to work in academics, business, and compliance, while males in Division II were more likely to work in development, facilities, media, and marketing, $\chi^{2}(31, n=973)=294.42, p<.001$, Cramér's $\mathrm{V}=.55$. In Division III, females were more likely to work in academics, business, and compliance, and males were more likely to work in facilities and media, $\chi^{2}(24, n=874)=189.75, p$ $<.001$, Cramér's V $=.47$.

\section{Discussion}

A purpose of this study is to examine the backgrounds of athletic administrators, excluding athletic directors, revealing their educational and experiential characteristics to help faculty who are preparing students and students who are pursuing these career paths. In addition, a purpose of this study is to reveal whether there is continued male domination of athletic administration and determine if administrators have different characteristics based on the NCAA division in which they work. The significant differences found across divisions and between males and females filled a major void in the literature about the educational and experiential backgrounds of athletic administrators.

Division I athletic administrators were more likely to have earned a doctorate than athletic administrators in Divisions II and III, possibly because this degree helped differentiate applicants when seeking positions in the most highly competitive division. While most NCAA-member institutions offered academic services to athletes, financial resources in Division I may allow them to hire larger staffs, many of whom held a doctorate, thus increasing academic credibility on campuses as well as suggesting advanced expertise. Not surprisingly, Division I athletic administrators were less likely to hold only a bachelor's degree in comparison with athletic administrators in Divisions II and III. This could be related to smaller institutions hiring coaches with only bachelor's degrees and then assigning them administrative responsibilities or promoting them into administrative roles after their coaching careers ended. In reading the online biographies of athletic administrators, the two authors examining Divisions II and III recorded a high percentage of current and former coaches. Another possibility in Divisions II and III was that many business managers, who may have functioned as accountants rather than athletic administrators, held only a bachelor's degree.

Division II athletic administrators were more likely to have earned a doctorate as well as less likely to hold only a bachelor's degree in comparison with athletic administrators in Division III. This suggested that individuals working in the higher competitive division needed advanced degrees to get hired and fulfill their responsibilities. It should be noted the online biographies examined stated many athletic administrators in Divisions II and III were currently completing advanced degrees, suggesting individuals earlier in their careers may have been seeking these degrees to qualify for jobs at a higher competitive level.

Female athletic administrators in the three divisions were more likely than males to have earned a master's degree, while male athletic administrators were more likely than females to have earned only a bachelor's degree. Advanced degrees may have been perceived as prerequisite credentials by some females, but less so for males, as Weaver and Chelladurai (2002) reported for athletic administrators by sex in Divisions I and III. That is, females may have decided to earn an advanced degree to develop greater expertise to obtain jobs as athletic administrators.

Athletic administrators differed in the academic majors of their highest degrees. In Division I, more athletic administrators held degrees in business and journalism or held a J.D. than those in Division II, who in turn were more likely to hold degrees in these fields than those in Division III. Preparation in these fields of study may have corresponded with an increased focus on a revenue-generating business model, more emphasis on media relations, and additional scrutiny about rules compliance. More Division III athletic administrators held degrees in an arts and sciences field, physical education, and communication than those in Divisions I and II. Communication and physical education may have been associated with serving as a sports information director and holding a joint appointment as a teacher in a Division III institution.

Female athletic administrators in Division I were more likely than males to have majored in arts and sciences or physical education, while males were more likely than females to have majored in journalism or communication. Females' majors may have been associated with working in academic services or as coaches, while males' majors prepared them for jobs in sports information and media relations, supporting the conclusions of Lumpkin et al. (2014). Females in Division II were more likely than males to have earned education, business, and J.D. degrees, possibly because they directed academic services, served as a business manager, or worked in compliance 
respectively. Female administrators working primarily in academic services and compliance also was reported by Burton et al. (2011), Hoffman (2011), Lough and Grappendorf (2007), Lumpkin et al. (2014), and Whisenant et al. (2002). Males in Division II were more likely to have earned their highest degrees in sport management and journalism than females. Females in Division III were more likely than males to have majored in arts and science or physical education; males were more likely than females to have earned degrees in communication. These majors may have reflected similar connections as in Division I with females working in academic services or coaching and males working in sports information or media relations.

Division I athletic administrators were more likely to have prior experience working in athletic administration than those in Divisions II and III, which probably was associated with greater availability of lower-level positions and advancement opportunities within larger programs. Interestingly, Division II athletic administrators were less likely to have prior experience in athletic administration than those in Division III. This may indicate Division II as a point of entry for individuals in other industries wanting to work in intercollegiate athletics or for recent graduates. Not surprisingly, females in Divisions II were less likely than males to have athletic administrative experience prior to starting their first jobs in athletics, while females in Division III were more likely than males to have prior experiences in intercollegiate athletics, suggesting Division II is even more likely to be an entry point for females wanting to work in intercollegiate athletics. This could be due to a higher number of jobs in Division II giving females without experience opportunities to begin their careers at that level.

Division III athletic administrators were more likely to have head coaching experience than those in the other two divisions. Possibly due to the unique characteristics and philosophy of Division III, a dearth of available athletic administration positions was found. In this situation, it was conceivable athletic administrators in Division III athletic departments performed multiple roles, including coaching one or more athletic teams. That administrators in Division III were more likely to have head coaching experience in college than those in Divisions I or II seemed to reveal a unique necessity of Division III athletic departments. That is, because of the smaller size of athletic departments in Division III, most coaches were assigned administrative responsibilities. For students interested in coaching and/or intercollegiate athletic administration, experience as an intercollegiate head coach would be useful. Those with a specific desire to work in Division III should be prepared to assume multiple roles, including head coach.

These latter findings seemed to suggest coaching experience was becoming a less frequent entry point into athletic administration in Division I, while coaching experience continued to serve that role in Division III. Female athletic administrators in the three divisions were more likely than males to have college head coaching experience. Additionally, males in Divisions I and II were more likely than females to have no coaching experience. These findings suggested more males began their athletic administrative careers in ways other than coaching, while females more often started as head coaches and later became athletic administrators.

Athletic administrators in Divisions I and II had fewer years in their current positions than those in Division III. Males in Division III had more years of experience in their positions than did females. These findings suggested Division III athletic administrators, and especially males, chose to work in this competitive level and remained there. This corroborated the report of Pack (2002) that $58.9 \%$ of Division III athletic directors had worked at their current institutions 10 to 29 years with between five and nine years of experience in this role at their current institutions, thus providing evidence that as athletic administrators first, and subsequently as athletic directors, they possibly preferred less of an emphasis on winning or enjoyed jobs comprised of diverse duties. Fitzgerald et al. (1994) suggested career experiences of Division I athletic directors made them more likely to have been employed as assistant and associate athletic directors because of staffing arrangements of more complex organizations at this level. That is, Division I athletic directors' experiences were likely to differ from those serving in this role in Divisions II and III because of numbers of teams and athletes, philosophies of programs, and prerequisite experiences required for managing and leading more complex athletic programs.

In a comparison of the mean number of athletic administrators by sex, there were more male than female associate athletic directors in Divisions I and II and more male than female assistant athletic directors in the three divisions, which confirmed the findings of Acosta and Carpenter (2012) and Lumpkin et al. (2014). Female athletic administrators in Division I were more likely to work in academics and compliance, while males were more likely to hold positions in media, facilities, and development. Division II females were more likely to work in academics, business, and compliance; males were more likely to hold positions in development, facilities, media, and marketing. Females in Division III were more likely to work in academics, business, and compliance, while males were more likely to hold positions in facilities and media. Hoffman (2011), Lough and Grappendorf (2007), and Lumpkin et al. 
(2014) also reported more females worked in academics and compliance in Divisions I and II, while more males held positions in facility and event management and media relations. In Divisions I and II, over $56 \%$ of female athletic administrators held positions in academics, compliance, or a combination of these two; over $35 \%$ of Division III female athletic administrators also worked in these two areas.

The implications of females stereotypically holding more athletic administrative positions in academics and compliance remained far-reaching. These internally focused positions kept females isolated from externally focused, decision-making roles in fundraising, media relations, and marketing. As such, females were less likely to network externally and thereby open doors for career advancement. As females seldom made financial decisions, they lacked opportunities to demonstrate leadership abilities in this vital aspect of the business of intercollegiate athletics, as concluded Eagly and Karau (2002) and Lumpkin et al. (2014).

In summary, this study found several significant differences across the divisions. Division I administrators were more likely to have a doctorate, more years of prior experience working in intercollegiate athletics, and no coaching experience. In all three divisions, males were more likely to hold positions in facilities and media; females were more likely to work in academics and compliance. In the three divisions female administrators were more likely to have a master's degree, prior intercollegiate athletic experience, and head coaching experience.

Success and advancement in intercollegiate athletics remained somewhat tenuous as males continued to dominate. Possibly faced with barriers in being hired into decision-making positions, females may be required to be more highly qualified than males. While experience was viewed as essential to career advancement, gaining experience in decision-making positions appears to remain limited for females. That is, females were still relegated to support positions such as academics and compliance, making it difficult for them to get the requisite experience to advance their careers.

\section{Conclusion}

To lead and manage athletic departments, administrators must develop and expand their business skills. This study provides many implications for those currently working or striving to work in college sports. Athletic departments as business enterprises should consider diversifying their staff and hiring more females whose expertise could help develop new revenue streams and increase program visibility.

Individuals planning to enter intercollegiate athletics as a profession should make informed decisions. With approximately a third of athletic administrators across all divisions holding their highest degree in sport management and almost a quarter of Division I administrators holding a business degree, business expertise seems essential for career success in intercollegiate athletics. Students earning sport management degrees should find this information encouraging. Additionally, approximately half of the administrators across all divisions hold at least a master's degree. The competition for jobs in a high-powered marketplace requires advanced knowledge and skills, especially for females. Also, females hoping to work in intercollegiate athletics need to gain experience in externally focused functions, such as finance, development, and marketing, while they are undergraduate students. This experience will increase their chances of getting hired into athletic administrative positions and advancing their careers.

Revealing statistics that inform us of the seemingly preferred characteristics athletic administrators possess provides students aspiring to athletic administrative positions with a blueprint of how to attain those positions. Students now have empirical data indicating the top five job responsibilities of athletic administrators, the percentage with bachelor's degrees, master's degrees, and doctorates, and to what extent coaching experience is needed, all broken down by division and sex. As each student assesses his or her planned career path, it is important to evaluate the preferred division to work in and make educational and experiential decisions based on this choice. The historic pathway of coaching and then moving into athletic administration seldom holds true in Division I as well as for the majority of administrators in Division II. Individuals who hope to move from other industries into intercollegiate athletics may have the highest likelihood of initially working in Division II.

Our research also divulges how females may be limited to certain areas within an athletic department (e.g., academics, compliance) due to the old boys' club and an apparent need to acquire a master's degree or doctorate more so than males to obtain an administrative position. Those in athletic departments hiring athletic administrators are now provided with data showing in which departments the differing skill sets and experiences provided by potential hires could be utilized to the benefit of the athletic department.

A limitation of this study is the reliance on data provided on athletic departments' websites to learn the backgrounds of athletic administrators, which was not always complete or detailed. Future research could use survey design to 
learn about the educational and experiential backgrounds of athletic administrators. In addition, future survey research could ask those hiring athletic administrators what educational and experiential qualifications they use when making hiring decisions. As intercollegiate athletics evolves and changes, continued research into the career paths and qualifications of administrators is valuable for those educating students, pursuing careers in intercollegiate athletics, and seeking to improve the representation of women in athletic administration.

\section{References}

Acosta, R. V., \& Carpenter, L. J. (2012). Women in intercollegiate sport: A longitudinal national study thirty-five year update 1977-2012. Retrieved from http://www.acostacarpenter.org/

Burton, L. J., Grappendorf, H., \& Henderson, A. (2011). Perceptions of gender in athletic administration: Utilizing role congruity to examine (potential) prejudice against women. Journal of Sport Management, 25, 36-45.

Eagly, A. H., \& Karau, S. J. (2002). Role congruity theory of prejudice toward female leaders. Psychological Review, 109, 573-598. http://dx.doi.org/10.1037//0033-295X.109.3.573

Fitzgerald, M. P., Sagaria, M. A., \& Nelson, B. (1994). Career patterns of athletic directors: Challenging the conventional wisdom. Journal of Sport Management, 8, 14-26.

Fuchs, V. J. (2003). A comparison of the career paths of NCAA female directors of athletics at Division I, II and III institutions and senior women administrators (Unpublished master's thesis). University of North Carolina at Chapel Hill, Chapel Hill, NC.

Grappendorf, H., Lough, N., \& Griffin, J. (2004). Profiles and career patterns of female NCAA Division I athletic directors. International Journal of Sport Management, 5, 243-261.

Hardin, R., Cooper, C. G., \& Huffman, L. T. (2013). Moving on up: Division I athletic directors' career progression and involvement. Journal of Applied Sport Management, 5(3), 55-78.

Hatfield, B. D., Wrenn, J. P., \& Bretting, M. M. (1987). Comparison of job responsibilities of intercollegiate athletic directors and professional sport general managers. Journal of Sport Management, 1, 129-145.

Hoffman, J. L. (2011). Inside the huddle: Gender stereotyping work among senior level women athletic administrators. International Journal of Sport Management, 12, 255-274.

Lapchick, R., Hoff, B., \& Kaiser, C. (2011). The 2010 racial and gender report card: College sport. Retrieved from http://www.bus.ucf.edu/documents/sport/2010-college-rgrc.pdf

Lough, N., \& Grappendorf, H. (2007). Senior woman administrator's perspectives on professional advancement. International Journal of Sport Management, 8, 193-209.

Lumpkin, A., Dodd, R. K., \& McPherson, L. (2014). Does a glass ceiling persist in intercollegiate athletics? Journal for the Study of Sports and Athletes in Education, 8(1), 33-46. http://dx.doi.org/10.1179/1935739714Z.00000000017

$\begin{array}{lllll}\text { National Collegiate Association. } & \text { (2014a). } & \text { Retrieved }\end{array}$ http://www.ncaapublications.com/productdownloads/D114.pdf

National Collegiate Athletic Association. http://www.ncaapublications.com/productdownloads/D214.pdf

$\begin{array}{lllll}\text { National Collegiate Athletic } & \text { Association. } & \text { (2014c). } & \text { Retrieved }\end{array}$ http://www.ncaapublications.com/productdownloads/D314.pdf

Pack, S. M. (2002). An assessment of the educational background and job responsibilities of National Collegiate Athletic Association Division III directors of athletics (Unpublished master's thesis). University of North Carolina at Chapel Hill, Chapel Hill, NC.

Spenard, J. C. (2013). An examination of National Collegiate Athletic Association Division I athletic directors. Kinesiology, Recreation, and Sport Studies Publications and Other Works. Retrieved from http://trace.tennessee.edu/utk_exerpubs/2

Weaver, M. A., \& Chelladurai, P. (2002). Mentoring in intercollegiate athletic administration. Journal of Sport Management, 16, 96-116.

Whisenant, W. A., Pedersen, P. M., \& Obenour, B. L. (2002). Success and gender: Determining the rate of 
advancement for intercollegiate athletic directors. Sex Roles, 47, 485-491. http://dx.doi.org/10.1023/A:1021656628604

Wilson, A. (2012). The status of women in intercollegiate athletics as Title IX turns 40. Retrieved from http://www.ncaapublications.com/productdownloads/TITLEIX.pdf

Wright, C., Eagleman, A. N., \& Pedersen, P. M. (2011). Examining leadership in intercollegiate athletics: A content analysis of NCAA Division I athletic directors. Sport Management International Journal, 7(2), 35-52.

Young, D. (1990). Mentoring and networking: Perceptions by athletic administrators. Journal of Sport Management, 4, 71-79. 